\title{
Response to Comments on Randomized Controlled Trial Comparing Everting Sutures with a Lateral Tarsal Strip for Involutional Lower Eyelid Entropion
}

\author{
Konstadinos G. Boboridis (D) · Elias A. Nakos
}

Received: February 6, 2020 / Published online: February 25, 2020

(C) The Author(s) 2020, corrected publication 2021

Keywords: Entropion; Everting sutures; Eyelid; Lateral tarsal strip; RCT

Sir,

We thank Dr Jamison et al. for their constructive comments on our recent publication [1]. The fact that this was only the second randomized controlled clinical trial (RCT) on involutional lower lid entropion indicates that there is a great need for scientific evidence in the field of oculoplastic surgery. Our results suggest that horizontal lower lid laxity contributes more to the manifestation of involutional lower lid entropion compared to the vertical lid laxity among other causative factors. Thus, horizontal tightening of the eyelid as a single procedure is more effective than vertical tightening for the management of involutional entropion.

Enhanced digital features To view enhanced digital features for this article go to https://doi.org/10.6084/ m9.figshare.11830845.

K. G. Boboridis $(\bowtie)$

Third Ophthalmology Department, Aristotle University of Thessaloniki, Thessaloniki, Greece e-mail: kosbob@otenet.gr

\section{E. A. Nakos}

Eye Clinic, 424 General Military Hospital, Thessaloniki, Greece
However, we have emphasized in this and previous publications that the combined procedure addressing both horizontal and vertical eyelid tightening is the golden standard for the management of senile entropion offering an optimum and long-lasting anatomical correction [2-4].

Dr Jamison et al. shared the anecdotal results of their Yorkshire entropion study comparing two types of combined procedures for entropion repair. Even unpublished data from incomplete RCTs offer valuable scientific information in a field with a paucity of clinical trials and the results of this Yorkshire study will be incorporated into the next update of a Cochrane systematic review on entropion surgery [3]. Their results of no recurrence in the group of lateral tarsal sling (LTS) with Jones retractor plication versus $6.3 \%$ in the group of LTS with everting sutures indicates that formal retractor plication is the most efficient method of vertical lid tightening. This is comparable to our findings in a previous trial where Jones retractor plication as a single procedure was proven to be far more efficient than the Wies procedure [2].

As the authors correctly pointed out, their RCT was unfortunate to suffer an unusually high dropout rate which resulted in the study being significantly underpowered. We agree that comparing combined procedures with high success rates over a longer follow-up period is 
required to identify subtle differences. It is unclear though why they have planned a study with such a long follow-up period of 12 years when there are reports of 4-year follow-up providing adequate observations [5].

We agree with the authors that there are significant difficulties in designing and completing surgical trials which require a longer follow-up period and involve an elderly population with progressing involutional changes, but practicalities should not introduce selection bias into the study.

Similarly, clinical decisions should be based on published evidence and it is only ethical to suggest the most effective combined procedure to anyone who requires entropion correction, despite their age or life expectancy. If other circumstances such as poor health or bedside surgery dictate the need for a simpler procedure, then everting sutures should be considered as a relatively effective option which does not require expertise and can be easily performed by a nurse practitioner [3].

\section{ACKNOWLEDGEMENTS}

Funding. No funding or sponsorship was received for this study or publication of this article.

Authorship. All named authors meet the International Committee of Medical Journal Editors (ICMJE) criteria for authorship for this article, take responsibility for the integrity of the work as a whole, and have given their approval for this version to be published.

Disclosures. Konstadinos G. Boboridis and Elias A. Nakos have no conflict of interest to disclose in relation to the content of this publication.

Compliance with Ethics Guidelines. This article is based on previously conducted studies and does not contain any studies with human participants or animals performed by any of the authors.

Open Access. This article is licensed under a Creative Commons Attribution-NonCommercial 4.0 International License, which permits any non-commercial use, sharing, adaptation, distribution and reproduction in any medium or format, as long as you give appropriate credit to the original author(s) and the source, provide a link to the Creative Commons licence, and indicate if changes were made. The images or other third party material in this article are included in the article's Creative Commons licence, unless indicated otherwise in a credit line to the material. If material is not included in the article's Creative Commons licence and your intended use is not permitted by statutory regulation or exceeds the permitted use, you will need to obtain permission directly from the copyright holder. To view a copy of this licence, visit http://creativecommons.org/licenses/by$\mathrm{nc} / 4.0 /$.

\section{REFERENCES}

1. Nakos EA, Boboridis KG, Kakavouti-Doudou AA, et al. Randomized controlled trial comparing everting sutures with a lateral tarsal strip for involutional lower eyelid entropion. Ophthalmol Ther. 2019;8: 397-406.

2. Boboridis K, Bunce C, Rose GE. A comparative study of two procedures for repair of involutional lower lid entropion. Ophthalmology. 2000;107:959-61.

3. Boboridis $\mathrm{KG}$, Bunce C. Interventions for involutional lower lid entropion. Cochrane Database Syst Rev. 2011;2011:CD002221.

4. Boboridis KG, Mikropoulos DG, Ziakas NG. Entropion. Ophthalmology. 2011;118:225-6 (author reply 26).

5. Altieri M, Kingston AE, Bertagno R, et al. Modified retractor plication technique in lower lid entropion repair: a 4-year follow-up study. Can J Ophthalmol. 2004;39:650-5. 